\title{
Dense mullite-zirconia-zirconium titanate ceramic composites by reaction sintering
}

\author{
N.M. Rendtorff ${ }^{\mathrm{a}, \mathrm{b}, *}$, S. Gómez ${ }^{\mathrm{a}}$, M.R. Gauna ${ }^{\mathrm{a}}$, M.S. Conconi ${ }^{\mathrm{a}}$, G. Suarez ${ }^{\mathrm{a}, \mathrm{b}}$, E.F. Aglietti ${ }^{\mathrm{a}, \mathrm{b}}$ \\ ${ }^{a}$ CETMIC Centro de Tecnología de recursos Minerales y Cerámica (CIC-CONICET La Plata), Con Centenario y 506, M.B. Gonnet 1897, Buenos Aires, Argentina \\ ${ }^{\mathrm{b}}$ Departamento de Química, Facultad de Ciencias Exactas, Universidad Nacional de La Plata, 47 y 115, La Plata 1900, Buenos Aires, Argentina
}

Received 1 September 2015; received in revised form 15 September 2015; accepted 16 September 2015

Available online 26 September 2015

\begin{abstract}
Materials from the $\mathrm{Al}_{2} \mathrm{O}_{3}-\mathrm{SiO}_{2}-\mathrm{ZrO}_{2}$ and the $\mathrm{Al}_{2} \mathrm{O}_{3}-\mathrm{SiO}_{2}-\mathrm{ZrO}_{2}-\mathrm{TiO}_{2}$ systems have several high temperature applications because they present the good refractoriness, chemical inertness, adequate mechanical and thermo-mechanical behaviors with a relatively good cost: performance ratio. In this work stoichiometric (3:2:1) molar incompatible mixtures of alumina $\left(\mathrm{Al}_{2} \mathrm{O}_{3}\right)$, zircon $\left(\mathrm{ZrSiO}_{4}\right)$ and titania $\left(\mathrm{TiO}_{2}\right)$ were slip casted and sintered in a $1300-1500{ }^{\circ} \mathrm{C}$ temperature range in order to obtain mullite $\left(3 \mathrm{Al}_{2} \mathrm{O}_{3} \cdot 2 \mathrm{SiO}_{2}\right)$, zirconia $\left(\mathrm{ZrO}_{2}\right)$ and zirconium titanate $\left(\mathrm{ZrTiO}_{4}\right)$ dense triple ceramic composite.

Both sintering and reaction occurred after the thermal treatments. Reaction progress and densification evolutions were established. Dense Triplex composite materials were achieved after $1500{ }^{\circ} \mathrm{C}$ treatments. The reaction-sintering was followed by XRD, TG-DTA, and dilatometry. Densification started at $1100{ }^{\circ} \mathrm{C}$ and the chemical reactions only started above $1300{ }^{\circ} \mathrm{C}$. Aluminum titanate $\left(\mathrm{Al}_{2} \mathrm{TiO}_{5}\right)$ was found to be an intermediate of the reaction after $1400{ }^{\circ} \mathrm{C}$ treatments. Materials treated below $1300{ }^{\circ} \mathrm{C}$ presented a partial densification of the unreacted starting powders. Resulting ceramic materials were characterized. The crystalline phases were evaluated, as well as the texture properties. The achieved microstructure consisted in interlocked multiphase ceramic with zirconia (monoclinic) grains. The achieved $\mathrm{Hv}$ and $K_{\mathrm{IC}}$ reached $9 \mathrm{GPa}$ and 4.3 $\mathrm{MPa} \mathrm{m}{ }^{1 / 2}$ respectively. The dense and interlocked ceramic microstructure and relative high mechanical properties of the developed material encourages several high temperature applications. Finally it can be pointed out that after $1500{ }^{\circ} \mathrm{C}$ treatments some detrimental grain growth was observed.
\end{abstract}

(c) 2015 Elsevier Ltd and Techna Group S.r.l. All rights reserved.

Keywords: A. Processing; C. Properties; D. Mullite; Zirconia; Zirconium titanate

\section{Introduction}

Composite materials have an important industrial and technological role. The designing capability of the manufacturer in properties and behaviors is enhanced by combining two or more different materials. However the final properties will not always be between the pure material ones, in fact in several cases the properties are considerably improved. Once the constituent phases and the processing conditions are

\footnotetext{
*Corresponding author at: CETMIC Centro de Tecnología de recursos Minerales y Cerámica (CIC-CONICET La Plata), Con Centenario y 506, M.B. Gonnet 1897, Buenos Aires, Argentina.

E-mail address: rendtorff@ cetmic.unlp.edu.ar (N.M. Rendtorff).
}

chosen the final phase content in the material becomes one of the most important processing variables $[1,2]$.

The mullite ceramics have had and will continue to have a significant role in the development of traditional and advanced ceramics [3-6]. Mullite is the only stable crystalline phase in the aluminosilicate system, under normal atmospheric pressure at room through elevated temperatures [3]. Its chemical composition ranges from $3 \mathrm{Al}_{2} \mathrm{O}_{3}-2 \mathrm{SiO}_{2}$ to approximately $2 \mathrm{Al}_{2} \mathrm{O}_{3}-\mathrm{SiO}_{2}$. It has received significant attention during the last decades as a potential structural material for high temperature applications [3-6].

Particularly mullite-zirconia composites are materials with important technological applications due to their good properties such as toughness, chemical stability, and high-creep 
resistance [7-12]. In practice they are employed in the glass industry and where high chemical and corrosion resistance are required. Zircon and alumina are largely employed as raw materials in their manufacture [13-15]. The reaction sintering processes is a suitable strategy for obtaining zirconia composites at comparatively lower costs than introducing zirconia as starting powder [16-19].

The addition of $\mathrm{TiO}_{2}$ to mullite-zirconia composites prepared from different alumina sources leads to change of reaction sintering, densification and microstructure which can alternately change the formation temperature and retention of $\mathrm{t}$ $\mathrm{ZrO}_{2}$ phase in these composites [20-23].

The mullite-zirconia composites containing different amounts of micro- and nano- $\mathrm{TiO}_{2}$ particles were prepared by reactionsintering of alumina and zircon powder by other authors using slip casting as shaping method [23]. Then, the physical properties, phase composition, flexural strength and microstructure of these composites were finally evaluated. This study confirmed the strong influence that nano- $\mathrm{TiO}_{2}$ particles exert on the microstructure and flexural strength of mullite-zirconia composites.

Zirconium titanate $\left(\mathrm{ZT}-\mathrm{ZrTiO}_{4}\right)$ is commonly used as a dielectric in microwave devices due to its high permittivity at microwave frequencies [24-26]. ZT has been proposed for structural and thermomechanical severe applications [27,28]. Zirconium titanate $\left(\mathrm{ZrTiO}_{4}\right)$ is a well-known compound in the field of electro-ceramics, as constituent of dielectric resonators and components for telecommunications, [29-34]. There is also a family of zirconium titanate ceramic pigments [35].

The traditional preparation of ZT ceramics is based on the solid-state reaction between $\mathrm{TiO}_{2}$ and $\mathrm{ZrO}_{2}$ powders at high temperatures. In order to improve the functional properties of the ceramics, expensive and energy consuming post-reaction treatments are generally needed. Chemical methods based on the co-precipitation of reactive precursors were developed to prepare high purity powders and to lower the cost of the postreaction treatments. The main features of the preparation methods of ZT powders were described by Navio et al. [33]. Controlled hydrolysis of alkoxides and sol-gel syntheses were also investigated to obtain fine particles. Spark plasma sintering of ZT materials has been recently reported [34].

Some materials from the $\mathrm{ZrO}_{2}-\mathrm{AI}_{2} \mathrm{O}_{3}-\mathrm{SiO}_{2}-\mathrm{TiO}_{2}$ quaternary system have been studied by other authors: The phase diagram has been reported and discussed [36], the projection through the $\mathrm{ZrO}_{2}$ corner showing secondary phases crystallizing during cooling from $\mathrm{ZrO}_{2}-\mathrm{Al}_{2} \mathrm{O}_{3}-\mathrm{SiO}_{2}-\mathrm{TiO}_{2}$ mixtures (Z-A-S-T) containing $60 \mathrm{wt} \% \mathrm{ZrO}_{2}$.

The zircon dissociation (Eq. (1)) and mullite formation (Eq. (2)) behavior was described for several compositions [37]. They showed that an interesting family of dense tough ceramics can by processed from inexpensive starting powders in the 1350$1500{ }^{\circ} \mathrm{C}$ range. Due to low cost and availability the starting powders chosen in this work are alumina, zircon and titania. The consequent thermal reactions were established; particularly a reaction sintering framework was described. The zircon dissociation and the formation of $\mathrm{ZrTiO}_{4}$ and $3 \mathrm{Al}_{2} \mathrm{O}_{3} \cdot 2 \mathrm{SiO}_{2}$ can be ensured from the phase diagram presented in the mentioned article (Eqs. (1)-(3)). The zircon dissociation [37] occurs at high temperatures also. Finally it should be emphasized that $\mathrm{TiO}_{2}$ forms stable solid solutions with $\mathrm{ZrO}_{2}$ and mullite. And according to Melo et. al. the solubility of $\mathrm{TiO}_{2}$ into $\mathrm{ZrO}_{2}$ and (mullite) is near $4 \mathrm{wt} \%$ [36].

$\mathrm{ZrSiO}_{4} \rightarrow \mathrm{ZrO}_{2}+\mathrm{SiO}_{2}$

$3 \mathrm{Al}_{2} \mathrm{O}_{3}+2 \mathrm{SiO}_{2} \rightarrow 3 \mathrm{Al}_{2} \mathrm{O}_{3} \cdot 2 \mathrm{SiO}_{2}$

$\mathrm{ZrO}_{2}+\mathrm{TiO}_{2} \rightarrow \mathrm{ZrTiO}_{4}$

The composition studied in the present work differs from the range presented in [36]. In fact it is a simpler one, with less alumina content and an integer molar relation. The concluded sintering mechanism was enhanced by the formation of a transient liquid phase at high temperatures. And probably this mechanism involves a decrease in the mechanical behavior at higher temperatures.

\subsection{Objectives}

The objective of the present work is to obtain a family of dense polyphasic ceramics, with mullite as continuous matrix, from inexpensive starting powders, and to establish the effect of the key processing variables on the material properties. Another objective is to evaluate the phase composition, the developed microstructure and other technological properties. The actually studied composition corresponds to the stoichiometric molar 3:2:1 which corresponds to the global reaction (Eq. (4)), to form a triple composite from three inexpensive raw ceramic powders.

$3 \mathrm{Al}_{2} \mathrm{O}_{3}+2 \mathrm{ZrSiO}_{4}+\mathrm{TiO}_{2} \rightarrow 3 \mathrm{Al}_{2} \mathrm{O}_{3} \cdot 2 \mathrm{SiO}_{2}+\mathrm{ZrO}_{2}+\mathrm{ZrTiO}_{4}$

Eq. (4) is equivalent to twice Eq. (1) plus Eqs. (2) and (3). Table 1 shows the label, formula and properties of the starting and final phases.

\section{Experimental procedure}

\subsection{Starting powders}

The zircon starting powder was zirconium silicate with $\mathrm{ZrO}_{2}:$ :64-65.5 wt\%, $\mathrm{SiO}_{2}: 33-34 \mathrm{wt} \%, \mathrm{Fe}_{2} \mathrm{O}_{3}: 0.10 \mathrm{wt} \%$ and $\mathrm{TiO}_{2}$ : $0.15 \mathrm{wt} \%$, mean diameter $\left(D_{50}\right)$ of $2.0 \mu \mathrm{m}$, specific gravity of $4.6 \mathrm{~g} / \mathrm{cm}^{3}$, melting point of $2200{ }^{\circ} \mathrm{C}$ and hardness (Mohs) of 7.5 (KreutzonitSuper, MahlwerkeKreutz, Germany). The second starting powder was Alumina (ALMATIS A-16SG) $\alpha$-alumina $\left(D_{50}: 0.5 \mu \mathrm{m}\right)\left(\mathrm{Al}_{2} \mathrm{O}_{3}: 99.8 \%, \quad \mathrm{SiO}_{2}\right.$ : $0.025 \mathrm{wt} \%)$ and the third was an industrial titania powder, $\left(\mathrm{TiO}_{2}\right.$ : $\left.99.7 \mathrm{wt} \%\right)$, with a crystalline Anatase-Rutile proportions of $95-5 \mathrm{wt} \%$ and a mean diameter $\left(D_{50}\right)$ of around $1.0 \mu \mathrm{m}$ (Mallinckrodt Chemical Works).

\subsection{Materials processing}

The processing route was chosen considering processing strategies reported for similar materials belonging to the 
Table 1

Formula and properties of the studied ceramics phases [38-44].

\begin{tabular}{|c|c|c|c|c|c|}
\hline & Formula & $\begin{array}{l}D_{\text {theo, }} \text { Density (theoretical) } \\
\left(\mathrm{g} \mathrm{cm}^{-3}\right)\end{array}$ & $\begin{array}{l}\alpha \text {, Expansion coefficient }\left(10^{-}\right. \\
\left.{ }^{6} \mathrm{C}^{-1}\right)\end{array}$ & $\begin{array}{l}E \text {, Elastic modulus } \\
(\mathrm{GPa})\end{array}$ & $\begin{array}{l}\sigma_{\mathbf{f}}, \text { Flexural strength } \\
(\mathrm{MPa})\end{array}$ \\
\hline Zircon & $\mathrm{ZrSiO}_{4}$ & 4.56 & 5 & 190 & 100 \\
\hline Alumina & $\mathrm{Al}_{2} \mathrm{O}_{3}$ & 3.96 & 8 & 380 & 500 \\
\hline Titania (rutile) & $\mathrm{TiO}_{2}$ & 4.23 & $8.4-11.8$ & 250 & 200 \\
\hline Titania (anatase) & $\mathrm{Ti} \mathrm{O}_{2}$ & $3.8-4.0$ & $8.4-11.8$ & 250 & 200 \\
\hline Aluminum Titanate & $\mathrm{Al}_{2} \mathrm{O}_{3} \cdot \mathrm{TiO}_{2}$ & 3.68 & 2 & 375 & 59 \\
\hline Zirconium Titanate & $\mathrm{ZrTiO}_{4}$ & 5.0 & 8.1 & 160 & 200 \\
\hline Mullite & $3 \mathrm{Al}_{2} \mathrm{O}_{3} \cdot \mathrm{SiO}_{2}$ & 3.2 & $\approx 4.5$ & 210 & 255 \\
\hline Zirconia (monoclinic) & $\mathrm{ZrO}_{2}$ & 5.6 & 10 & 200 & 200 \\
\hline
\end{tabular}

$\mathrm{ZrO}_{2}-\mathrm{Al}_{2} \mathrm{O}_{3}-\mathrm{SiO}_{2}-\mathrm{TiO}_{2}$ system [45-50]. Molar 3:2:1 Stoichiometric mixtures of alumina-zircon-titania samples were slip casted in plaster molds from a dispersion with $50 \%$ of solid content (stirred and sonicated), at $\mathrm{pH} 10.0$ and with $0.3 \mathrm{wt} \%$ of Dolapix dispersant (Dolapix CE64, Zschimmers and Schwartz) and $\mathrm{NH}_{4} \mathrm{OH}$. Dried probes were fired in an electric furnace with a heating rate of $10{ }^{\circ} \mathrm{C} / \mathrm{min}$ up to different temperatures between 1300 and $1500{ }^{\circ} \mathrm{C}$ with $2 \mathrm{~h}$ soaking. Samples were labeled Ti where $\mathrm{i}$ is the maximum temperature of the thermal treatment.

\subsection{Characterizations}

Simultaneous thermo-gravimetric and thermo-differential analysis was performed up to $1500{ }^{\circ} \mathrm{C}$. To understand the sintering behavior, thermo mechanical analysis on vertical prismatic $\left(20.0 \times 3.5 \times 3.5 \mathrm{~mm}^{3}\right)$ sample was performed. Both thermal analyses were carried out with a $5{ }^{\circ} \mathrm{C} / \mathrm{min}$ heating rate in air atmosphere (TG-DTA and TMA Rigaku Evo plus II, Japan) [51].

Density and apparent porosity of the sintered samples were evaluated by the Archimedes method. The crystalline phases of sintered samples were determined by X-ray diffraction (XRD) using $\mathrm{CuK} \alpha$ radiation operating at $40 \mathrm{kV}$ and $300 \mathrm{~mA}$, and quantified by the Rietveld-method [52-54]. The microstructure analysis was made by a scanning electron microscopy (SEM) (JEOL, JCM- 6000). To assess the densification of the composite the theoretical density $\left(D_{\text {theo }}\right)$ of the composite was estimated through the following equation:

$D_{\text {Theo }}=\sum_{i=0}^{n} V_{i} \times D_{i}$

where $V_{\mathrm{i}}$ is the volume fraction of each crystalline phase (i) evaluated by XRD-Rietveld quantification and $\mathrm{Di}$ is the theoretical density of each phase.

Vickers Hardness $(\mathrm{Hv})$ and fracture toughness $\left(K_{\mathrm{IC}}\right)$ of the obtained ceramics were evaluated with a Vickers indentation machine (Buhueler, USA). At least six indents submitted to a $5 \mathrm{Kg}$ load for each sample were performed. The fracture toughness was calculated from the developed crack lengths by the following equation [55-56]:

$K_{\text {IC }}=\delta\left(\frac{E_{\text {Theo }}}{H}\right)^{\frac{1}{2}} \frac{P}{c^{\frac{3}{2}}}$ where $E$ is the elastic modulus, $H$ is the Vickers Hardness, $P$ is the indentation test load, $c$ is the indentation crack length. Finally $\delta$ is a material-dependent constant that was assumed to be 0.018 . The crack lengths were measured immediately after the indentation in order to avoid slow crack growth after removing the load. The elastic modulus $\left(E_{\text {Theo }}\right)$ of the composite was not measured. It was estimated employing the following equation:

$E_{\text {Theo }}=\sum_{i=0}^{n} V_{i} \times E_{i}$

Once more $V_{\mathrm{i}}$ is the volume fraction of each crystalline phase (i) evaluated by XRD-Rietveld quantification and $E_{\mathrm{i}}$ is the Elastic modulus of each phase, literature figures were employed (Table 1).

Finally the dilatometric behavior of the completely converted material was established (Rigaku Evo II, Japan). A theoretical thermal expansion coefficient $\left(\alpha_{\text {Theo }}\right)$ was also estimated by composite law approach from the volume fractions $\left(V_{\mathrm{i}}\right)$ and the individual thermal expansion coefficients $\left(\alpha_{\mathrm{i}}\right)$, in order to compare with the experimental results.

$\alpha_{\text {Theo }}=\sum_{i=0}^{n} V_{i} \times \alpha_{i}$

\section{Results and discussion}

\subsection{Thermal behavior of the slip casted mixture up to $1500{ }^{\circ} \mathrm{C}$}

The simultaneous TG-DTA analysis was carried out, no process involving mass loss or gain was detected. On the other hand, the only process observed by the DTA analysis is an exothermic process that started slightly above $1300{ }^{\circ} \mathrm{C}$. Fig. 1 shows the DTA curve. The end of these thermal processes was not within the studied temperature range (room temperature to $1500{ }^{\circ} \mathrm{C}$ ). This peak might be related to the subsequent chemical processes involved in the reaction sintering. This could be the zircon dissociation, or the formation of new phases: mullite $\left(3 \mathrm{Al}_{2} \mathrm{O}_{3} \cdot 2 \mathrm{SiO}_{2}\right),\left(\mathrm{AlTi}_{2} \mathrm{O}_{5}\right)$ and /or $\mathrm{ZrTiO}_{4}$ formation.

Fig. 1 also shows the complete dilatometric curve of the unfired sample from room temperature to $1500{ }^{\circ} \mathrm{C}$ and the reverse cooling cycle down to $300{ }^{\circ} \mathrm{C}$. The sintering starts at 
$1100{ }^{\circ} \mathrm{C}$. A remarkable double ribbon behavior can be observed near the final temperature set. Fig. 2 shows a detail of this final zone. From this analysis, the sintering processes can be observed; evidently the sintering starts gradually at $1100{ }^{\circ} \mathrm{C}$ and presents a high rate over $1200{ }^{\circ} \mathrm{C}$. At this heating rate, the shrinkage rate is almost constant up to $1420{ }^{\circ} \mathrm{C}$. In Fig. 2, the detail of the double ribbon behavior can be easily observed. A remarkable relative expansion can be observed after the described constant rate zone, from 1420 to $1480{ }^{\circ} \mathrm{C}$. This result corresponds with the new phases formed in the reaction sintering processes. Taking into account that the theoretical densities of the products are in some cases lower than the reagents (see Table 1), this relative expansion is expectable. After $1480{ }^{\circ} \mathrm{C}$ a second shrinking stage can be delimited up to the end of the studied temperature range $\left(1500{ }^{\circ} \mathrm{C}\right)$. This should be associated to the loss of porosity of the fully converted newly formed phases. The cooling reverse cycle shows a continuous gradual shrinkage from this temperature to $300{ }^{\circ} \mathrm{C}$ and presumably to room temperature.

In summary, from this macroscopic analysis, both sintering and chemical processes limits could be detected, while the first one starts at $1100{ }^{\circ} \mathrm{C}$, the second one only at higher temperatures around $1380{ }^{\circ} \mathrm{C}$. The performed XRD analysis (Section 3.3) supported this result.

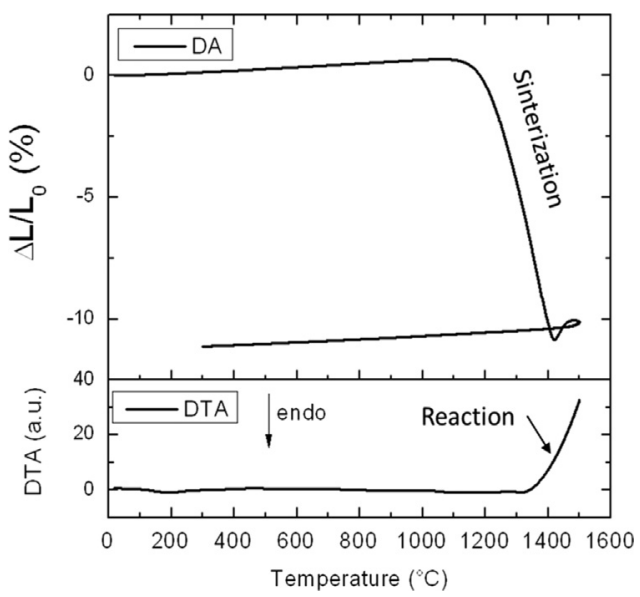

Fig. 1. Dilatometric analysis (DA) and differential thermal analysis (DTA) of the unfired slipcasted 3:2:1 mixture.

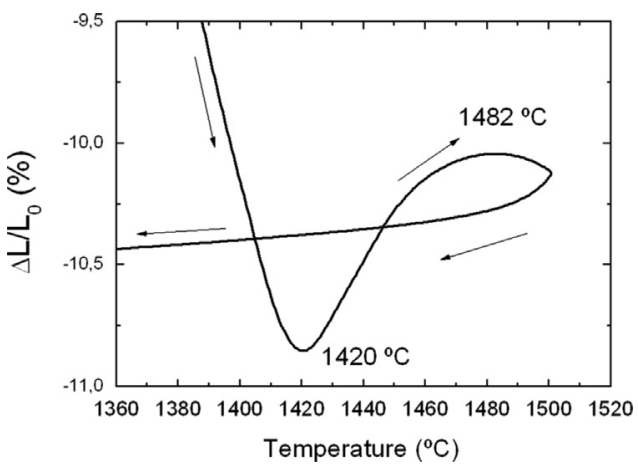

Fig. 2. Detail of the Dilatometric analysis (DA) the unfired slip-casted 3:2:1 mixture. Labeled temperature corresponds to the local minimum and maximum.

\subsection{Evolution of the textural properties as a function of the sintering temperature.}

Fig. 3 shows the evolution of the textural properties (density and porosity) with the final sintering temperature of the developed materials evaluated by the Archimedes immersion method. These can be assumed as sintering parameters.

As expected, the density increased with the temperature, and the porosity was gradually decreased up to almost null values. The density of sample sintered at $1300{ }^{\circ} \mathrm{C}$ was around $3.2 \mathrm{~g} /$ $\mathrm{cm}^{3}$ the achieved density at $1500{ }^{\circ} \mathrm{C}$ is $3.7 \mathrm{~g} / \mathrm{cm}^{3}$. The plateau observed for $\mathrm{T} 1400$ and $\mathrm{T} 1450$ (at $3.55 \mathrm{~g} / \mathrm{cm}^{3}$ ) corresponds to the incomplete chemical processes observed in the dilatometric study described in the following sections.

The porosity was lowered down from $20 \%$ to less than $1 \%$ for the sample sintered at $1500{ }^{\circ} \mathrm{C}$. The initial porosity of the green body was $35-45 \%$. Showing that for the T1300 material the sintering processes is advanced, but not complete. On the other hand, the sintering is complete for the T1500 material. This result was also observed in the previous section where the initiation of the sintering was established at $1100{ }^{\circ} \mathrm{C}$. Materials fired at 1400 and $1450{ }^{\circ} \mathrm{C}$ (T1400 and 1450) presented low porosities below $5 \%$; depending on the application these materials can be understood as dense materials. However the incomplete reaction is observed, the equilibrium state is not reached.

\subsection{Crystalline phase evolutions}

Diffraction patterns of the materials sintered at different temperature are shown in Fig. 4. (T1300, T1400, T1450, T1500). T1300 composite shows the presence of the reagents: alumina, zircon and titania (rutile) phases. Evidencing that after this treatment the chemical processes have not started. This result was inferred from the dilatometric behavior as well (Fig. 1).

On the other hand the patterns of T1400 and T1450 evidence that the chemical reactions occurs but not completely. Six crystalline phases were detected and quantified (Fig. 5): two of the reagents (alumina, zircon) and mullite, zirconia in the monoclinic polymorph, zirconium titanate and of aluminum titanate.

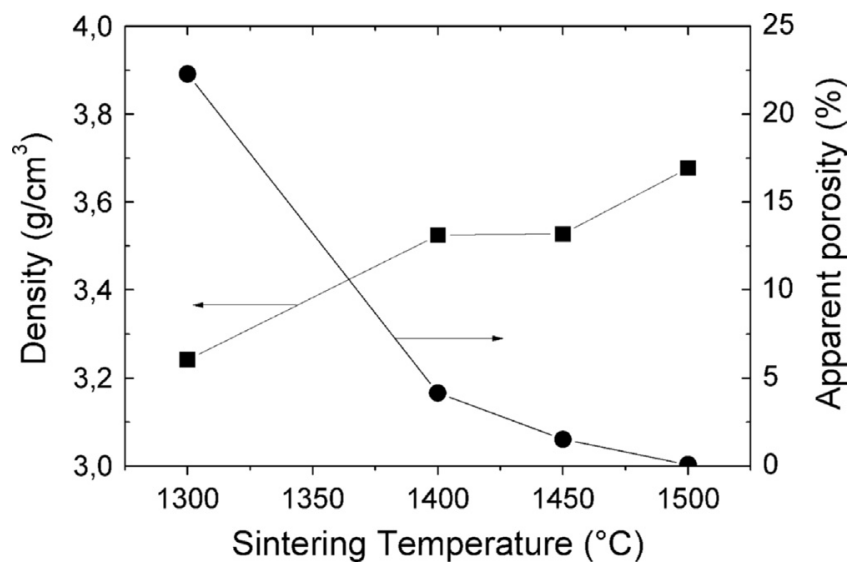

Fig. 3. Density and apparent porosity of the fired samples as a function of the maximum temperature of the sintering temperature. 


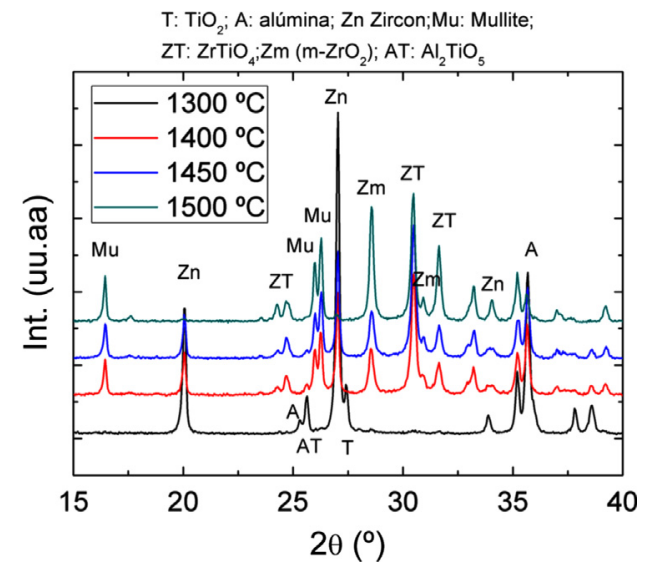

Fig. 4. XRD patterns of the composite materials (principal peaks were labeled).

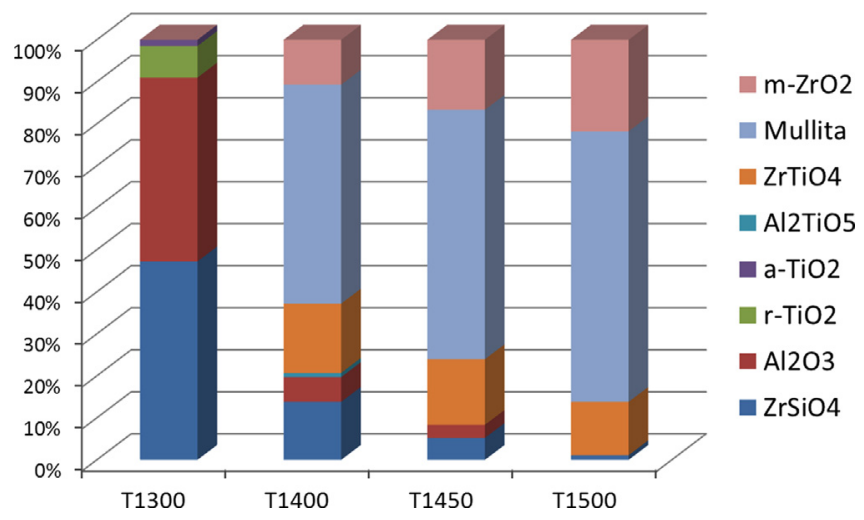

Fig. 5. Crystalline phase weight content of the studied materials.

Finally in the T1500 material the same peaks could be detected with the only exception of the disappearance of the $\mathrm{AlTi}_{2} \mathrm{O}_{5}$ phase, which seems to be an intermediate phase during the processes. This is expectable taking into account the phase diagram reported by Melo et al. [35].

The Rwp parameters obtained were satisfactory (below 30) in all the cases. Evidently T1300 material presents no chemical processes and T1500 presents a full conversion of the Eqs. ((1)-(3)) with no evidence of the reagents (alumina-zircontitania). The small discrepancies with the stoichiometric results can be explained by errors in the quantification methodology and the possible existence of Solid Solutions. Finally in the fully converted triple composite the aimed equilibrium phases were achieved (A3S2, ZT, Z). As expected, after intermediate conditions, the reactions were partially advanced hence T1400 is a polyphasic ceramic with 5 crystalline phases (A, ZS, $\mathrm{A} 3 \mathrm{~S} 2, \mathrm{ZT}, \mathrm{Z})$ due to the partial advance of the described chemical processes.

\subsection{Microstructure (SEM)}

SEM micrographs $(2000 \times)$ of the T1300, T1400, T1450 and T1500 materials are respectively shown in Fig. 6A-D, three different microstructures can be observed (Fig. $6 A \neq 6 B=6 C \neq 6 D$ ). Bearing in mind the $\mathrm{XRD}$ results it can be clearly seen in Fig. $6 \mathrm{~A}$ that the unreacted alumina, zircon and titania powders were partially sintered due to the thermal treatment. No important chemical reaction occurred besides de Anatase-Rutile conversion [57]. The grain size is equivalent to the starting powder size (from data sheet). The porosity principally consists in packing defects between the grains.

The middle T1400 and T1450 materials (Fig. 6B and C), show the developed interlocked poly phasic (five) ceramic microstructure, with $\approx 5 \%$ and $\approx 2 \%$ of porosity respectively. The sintering is advanced but not strictly complete. The pore size is important and of several microns, local highly dense zones can be detected. Different phases can be delimited, grains correspond to the one detected by XRD. Remembering that the color is directly related to the atomic number, in the present group, the following sequence zirconia, zirconium titanate, zircon, mullite and alumina (first two and the last two are difficult to differentiate). The grain size is slightly higher than the one observed in the unreacted T1300; hence no important grain growth occurred during reaction sintering, this was only observed in T1500 (Fig. 6D) where evidently the conditions favor the grain growth.

For a better visualization Fig. 7 shows Fig. 6D and a digitally enlarged detail of the image. In the detail the different observed phases are labeled (zirconia, zirconium titanate, mullite, pore and crack). No important porosity can be observed. Crystalline phases are mullite, zirconia and the zirconium titanate. The mullite phase forms a continuous phase in which the $\mathrm{ZrO}_{2}, \mathrm{ZrTiO}_{4}$ disperse grains are distributed. While zirconia grains are rounded and present a lighter color the $\mathrm{ZrTiO}_{4}$ grains present a more irregular shape and are in fact a bit darker than the zirconia ones. In T1500 the grain size is higher $(\approx 5 \mu \mathrm{m})$ than the one observed in T1400 ( $\approx 2 \mu \mathrm{m}$ ), evidencing a grain growth during the last part of the processing. The sintering process is accompanied by a grain growth. The sintering and reaction mechanism proposed in a similar system was the occurrence of a transient liquid phase. This can also explain the shape and size of the $\mathrm{ZrTiO}_{4}$ grains and the effective sintering achieved (Table 2).

For the T1500 material the microstructure is a well-defined mullite (dark gray) ceramic matrix with a homogeneous distribution of imbibed zirconia and zirconium titanate grains (light gray, the second slightly darker), this microstructure is comparable to the typical dispersoidal mullite zirconia composites [7-19] but with the addition $\mathrm{ZrTiO}_{4}$ phase. This interlocked microstructure with the imbibed zirconia grains has been fully described and several toughening mechanisms have been proposed to be possible to occur in this kind of materials $[58,60-62]$.

\section{5. "Composite law" theoretical properties}

After the crystalline phase quantification, performed by the Rietveld refinement, the theoretical properties of the developed composites can be estimated. The differences between the achieved experimental properties and the theoretical values 

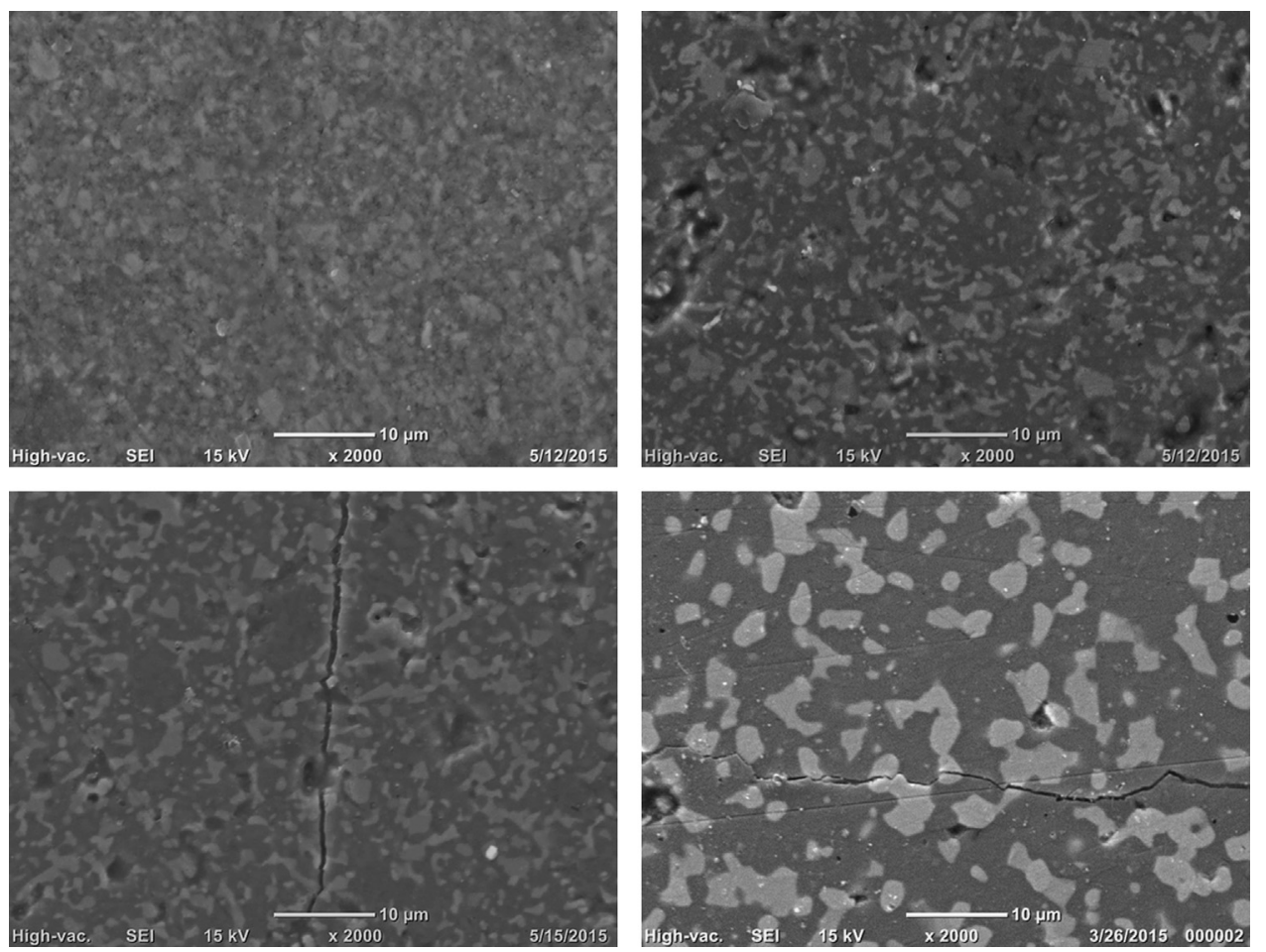

Fig. 6. SEM images $(2000 \times)$ of the T1300, T1400, T1450 and T1500 materials (A, B, C and D respectively); indentation cracks can be observed in T1400 and $\mathrm{T} 1500$.

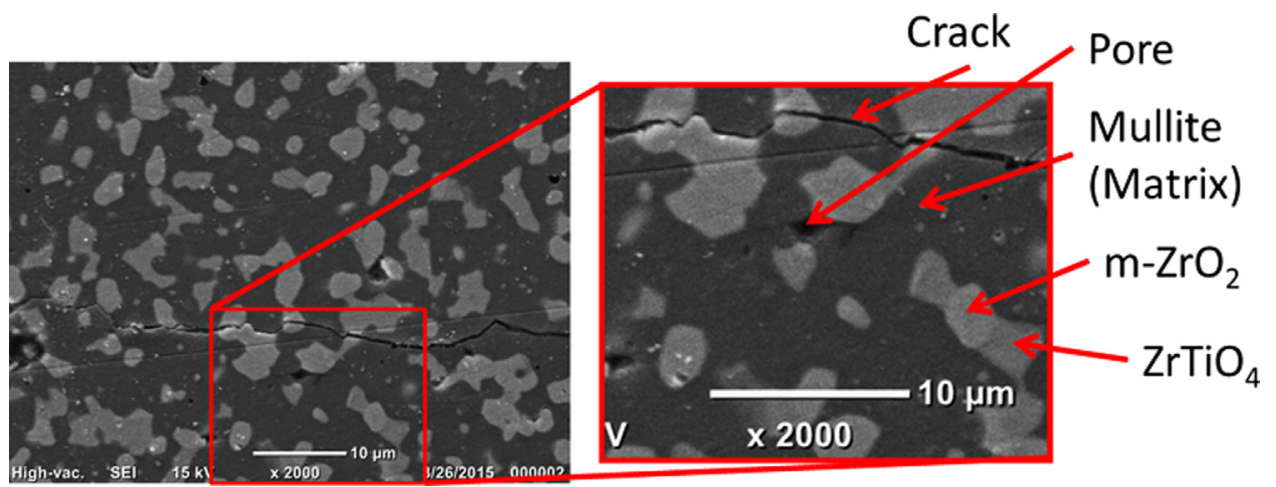

Fig. 7. SEM image of the T1500 material with a detail and the phase labels.

might be explained in terms of the developed microstructure; specially the configuration and pore presence. Table 3 shows the calculated values.

As expected, the density behavior is clear, with two situations. A partially sintered and un-reacted material (T1300) presents a higher density $(\approx 10 \%)$ than the reaction sintered composites processed at higher temperatures (T1400-T1450-T1500). In particular these three present similar $D_{\text {theo }}$.

The relative densification can be calculated; this illustrates the densification process which occurred during the thermal processing of the composites. The archived density defines the composites as dense materials; the presence of close porosity can explain the small difference.

The calculated thermal expansion coefficients $\left(\alpha_{\text {theo }}\right)$ are shown in Table 3, the values obtained fall within the 5.6-
$6.9 \times 10^{-6}{ }^{\circ} \mathrm{C}^{-1}$ range being lower than $\mathrm{ZrTiO}_{4}$ value but higher than zircon and mullite materials (Table 1). Finally the calculated elastic modulus show also a decreasing behavior with the firing temperature and the reaction advance reaching a $200 \mathrm{GPa}$ limit for fully converted materials T1500. These values were used to calculate the fracture toughness by the indentation method shown in the next section. The porosity was not taken into account.

\subsection{Reaction sintering}

To illustrate globally the reaction sintering processes a densification-reaction evolution correlation was performed (Fig. 8). The densification was assumed as the ratio between the Archimedes density and the composite law density, and the 
Table 2

Crystalline phase composition of the studied materials evaluated by the XRD-Rietveld method (wt\%).

\begin{tabular}{|c|c|c|c|c|c|c|c|c|}
\hline $\mathbf{T}$ & $\mathrm{ZrSiO}_{4}$ & $\mathbf{A l}_{2} \mathbf{O}_{3}$ & $\mathrm{r}-\mathrm{TiO}_{2}$ & $\mathrm{a}^{-\mathrm{TiO}_{2}}$ & $\mathrm{Al}_{2} \mathrm{TiO5}$ & $\mathrm{ZrTiO}_{4}$ & $3 \mathrm{Al}_{2} \mathrm{O}_{3} \cdot \mathrm{SiO}_{2}$ & $\mathrm{~m}-\mathrm{ZrO}_{2}$ \\
\hline T1300 & 47.2 & 43.8 & 7.5 & 1.5 & 0 & 0 & 0 & 0 \\
\hline T1400 & 13.8 & 5.9 & 0 & 0 & 1 & 16.5 & 52.1 & 10.7 \\
\hline T1450 & 5 & 3 & 0 & 0 & 0 & 15 & 57 & 16 \\
\hline T1500 & 1.1 & 0 & 0 & 0 & 0 & 12.7 & 64.4 & 21.8 \\
\hline
\end{tabular}

Table 3

Values of the $D_{\text {theo }}$ and $E_{\text {theo }}$.

\begin{tabular}{|c|c|c|c|c|}
\hline $\mathbf{T}$ & $\begin{array}{l}D_{\text {theo }}=\sum V_{i} d_{i} \\
\left(\mathrm{~g} \mathrm{~cm}^{-3}\right)\end{array}$ & $\begin{array}{l}\text { Densification: } \\
D_{\text {exp }} / D_{\text {theo }}(\%)\end{array}$ & $\begin{array}{l}\alpha_{\text {theo }}=\sum V_{i} \alpha_{i} \\
\left(10-6{ }^{-1}\right)\end{array}$ & $\begin{array}{l}\boldsymbol{E}_{\text {theo }}=\sum \boldsymbol{V}_{i} \boldsymbol{E}_{\boldsymbol{i}} \\
(\mathrm{GPa})\end{array}$ \\
\hline T1300 & 4.24 & 76.45 & 6.87 & 284.6 \\
\hline T1400 & 3.81 & 92.51 & 5.58 & 212.1 \\
\hline T1450 & 3.76 & 93.81 & 5.66 & 207.3 \\
\hline T1500 & 3.73 & 98.58 & 5.64 & 203.7 \\
\hline
\end{tabular}

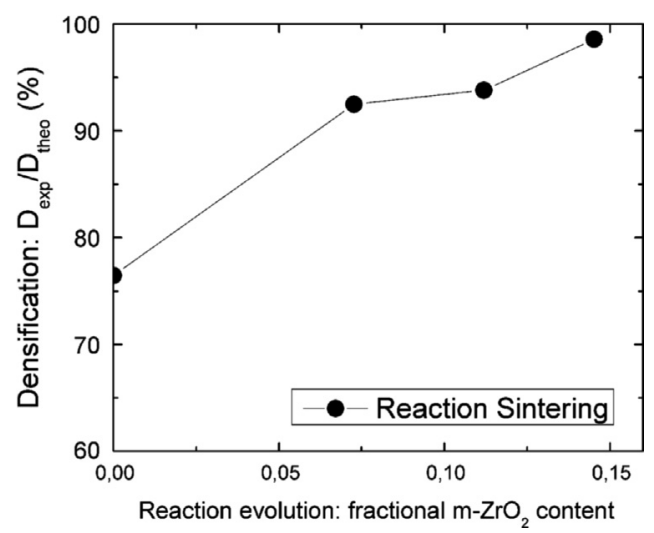

Fig. 8. Reaction sintering; densification as a function of reaction evolution (zirconia formation) of the studied materials.

reaction advance was illustrated as the zirconia formation ratio. Fig. 8 shows the reaction sintering behavior of the developed ceramic material under these sintering conditions. Considering the conforming method for the green body was obtained only around the $60 \%$ of compaction degree, it is clear that the deification stage starts before the solid state reactions.

\subsection{Mechanical properties ( $H v$ and $\left.K_{I C}\right)$}

Table 4 shows the values of the Vickers hardness and the fracture toughness obtained for the studied materials. An estimated value of the elastic modulus was used to calculate $K_{\text {IC }}$ (Eq. (7)). Remarkably the values achieved for $K_{\text {IC }}$, between 3.5 and $4.3 \mathrm{MPa} \mathrm{m}^{1 / 2}$, are high in comparison with other mullite matrix dispersoidal composites [60]. These values evidence the presence of toughening mechanisms in the developed microstructures. On the other hand the values of $\mathrm{Hv}$ are within the reported values for similar materials [60].
Table 4

Vickers Hardness $(\mathrm{Hv})$ and Fracture Toughness $\left(K_{\mathrm{IC}}\right)$ of the developed composites, error is expressed in percentages.

\begin{tabular}{lllll}
\hline $\mathbf{T}$ & $\mathbf{H v}(\mathbf{M P a})$ & Error $(\boldsymbol{\%})$ & $\boldsymbol{K}_{\mathbf{I C}}\left(\mathbf{M P a ~ m}^{\mathbf{1} \mathbf{2}}\right)$ & Error $(\boldsymbol{\%})$ \\
\hline T1300 & 4990 & 1.6 & 3.53 & 15 \\
T1400 & 7090 & 2.0 & 4.29 & 12 \\
T1450 & 7640 & 3.9 & 3.91 & 23 \\
T1500 & 8900 & 3.1 & 3.90 & 11 \\
\hline
\end{tabular}

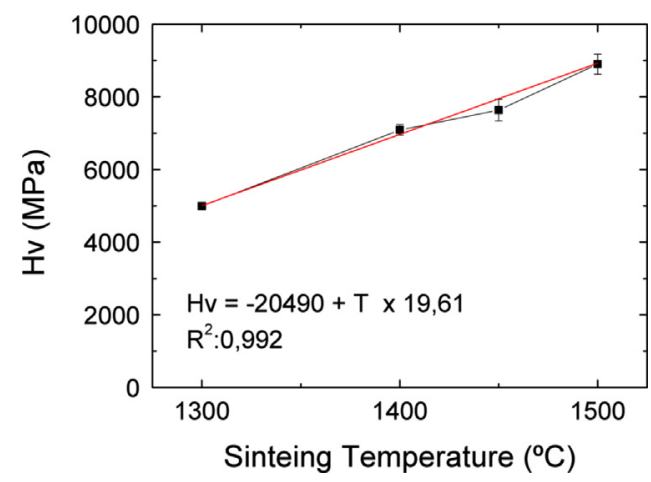

Fig. 9. Vickers Hardness $(\mathrm{Hv})$ and fracture Toughness $\left(K_{\mathrm{IC}}\right)$ of the composite materials as a function of the sintering temperature.

The hardness $(\mathrm{Hv})$ is plotted as a function of the sintering temperature in Fig. 9. The $\mathrm{Hv}$ progressively increased in the temperature range $\left(1300-1500{ }^{\circ} \mathrm{C}\right.$ ) from $5000 \mathrm{MPa}$ up to $9000 \mathrm{MPa}$, a linear fitting was performed; results are shown in Fig. 9 as well. This correlation was previously observed in other materials [58,59]. The $K_{\mathrm{IC}}$ behavior is related to the developed microstructure $[58,61,62]$.

The behavior of the fracture toughness with the sintering temperature is different; $K_{\mathrm{IC}}$ is almost constant within the studied range. Particularly the T1300 presented the lower value; this was expectable based in the fact of the incipient reaction degree achieved. T1400 and T1450 presented similar values, the second with a higher dispersion on the achieved value. Finally T1500 presented a slightly lower value of $K_{\text {IC }}$, this might be explained by the the grain size increase observed.

Toughening enhancement can be obtained by incorporating zirconia particles $\left(\mathrm{ZrO}_{2}\right)$ in a ceramic matrix and (or) by developing an interlocking microstructure [58,60-62]. Several concurrent mechanisms are involved in the toughening: stress induced transformation, micro-cracking, crack bowing and crack deflection and also the thermal expansion mismatch. 

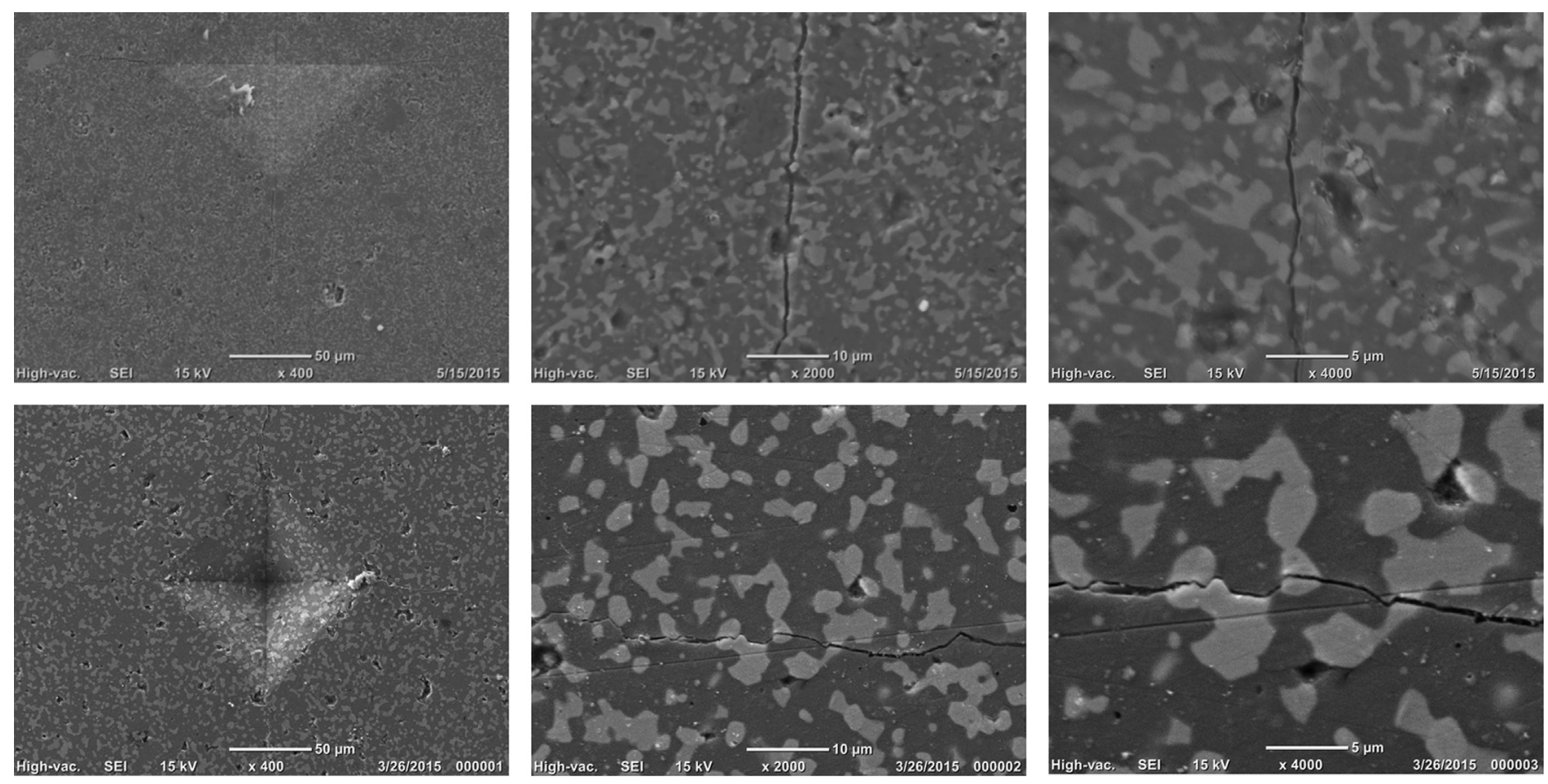

Fig. 10. Vickers indent and crack developed for the T1450 and T1500 materials.

However, as the content of tetragonal zirconia is nearly negligible, the transformation toughening mechanism should be discarded as first approach.

Fig. 10 shows the Vickers indent in the polished surface of T1450 and 1500 materials. The homogeneous microstructure is easily observed. The relation between the indent size and the microstructure shape are adequate to apply the indentation method [54-55]. However the effect of the porosity in $\mathrm{Hv}$ and $\mathrm{K}_{\mathrm{IC}}$ is not clear hence the Vickers test is always carried out in local porous free zone. This fact is not addressed in this work.

Fig. 10 shows Vickers indentation over the polished surface of the T1450 and T1500 materials, which present the higher sintering grade. The tortuous crack typical path can be observed. The crack is very directional opposite to the indent center and perpendicular between each other. But in a local point of view some acute deflections related to grain boundaries and zirconia presence are responsible for the toughness of the composite material. This can explain the high $K_{\mathrm{IC}}$ achieved. The difference in the grain size between T1450 and T1500 ( $2-3$ times bigger) can explain the toughness decrease observed at the higher temperature treatments. This effect is more important than the reaction advance (Eqs. (1)-(3)) or the observed residual porosity (only 2\%). Perhaps it is due to the presence of interlocked grains that can be observed in both microstructures independently of the fully conversion and higher porosity.

In the future a fine optimization can be performed, optimizing the final sintering program by changing the temperature rates (or adding an intermediate dwelling time) to enhance or restrict the three competitive processes: chemical conversion, pore disappearance (sintering) and grain growth. The first two are evident advantages and that it is well known that the grain growth is detrimental for the mechanical and thermomechanical performance of the structural ceramic materials.

\section{Conclusions}

A series of ceramic composites from the $\mathrm{Al}_{2} \mathrm{O}_{3}-\mathrm{SiO}_{2}-\mathrm{ZrO}_{2}-\mathrm{TiO}_{2}$ system were elaborated, the processing route employed consisted in pressureless sintering of slip casted inexpensive Alumina, Zircon, Titania fine powders $\left(D_{50} \approx 1 \mu \mathrm{m}\right)$. Particularly the stoichiometric (3:2:1) molar. Incompatible mixtures of alumina $\left(\mathrm{Al}_{2} \mathrm{O}_{3}\right)$, zircon $\left(\mathrm{ZrSiO}_{4}\right)$ and titania $\left(\mathrm{TiO}_{2}\right)$ were slip casted and sintered in the $1300-1500{ }^{\circ} \mathrm{C}$ temperature range in order to obtain mullite $\left(3 \mathrm{Al}_{2} \mathrm{O}_{3} \cdot 2 \mathrm{SiO}_{2}\right)$, zirconia $\left(\mathrm{ZrO}_{2}\right)$ and zirconium titanate $\left(\mathrm{ZrTiO}_{4}\right)$ dense triple ceramic composite. Not fully converted materials (fired at intermediate temperatures) resulted in five phase ceramic composites with a tough interlocked microstructure and low porosities ( $>5 \%$ ), in several applications these could be considered dense microstructures.

Both sintering and reaction occurred after the thermal treatments. Reaction evolution and densification were established. Densification started at $1100{ }^{\circ} \mathrm{C}$ and the chemical reactions only started above $1300{ }^{\circ} \mathrm{C}$ with $200{ }^{\circ} \mathrm{C}$ of difference. Dense Triplex composite materials were achieved after $1500{ }^{\circ} \mathrm{C}$ treatments. Aluminum titanate $\left(\mathrm{Al}_{2} \mathrm{TiO}_{5}\right)$ was found to be and intermediate of the reaction after $1400{ }^{\circ} \mathrm{C}$ treatments. Materials treated below $1300{ }^{\circ} \mathrm{C}$ presented a partial densification of the unreacted starting powders. Resulting ceramic materials were characterized. The crystalline phases were evaluated by the Rietveld method, as well as the texture properties. The achieved microstructure consisted in interlocked multiphase ceramic with zirconia (monoclinic) grains. The achieved $\mathrm{Hv}$ and $K_{\mathrm{IC}}$ reached $9 \mathrm{GPa}$ and $4.3 \mathrm{MPa} \mathrm{m}^{1 / 2}$. Hardness was directly correlated with the densification. It can be pointed out that after $1500{ }^{\circ} \mathrm{C}$ treatments some detrimental grain growth was observed. Finally it can be concluded that the dense and interlocked refractory microstructure and relative 
high mechanical properties of the developed materials encourages several high temperature applications.

\section{References}

[1] Niihara, Koichi New design concept of structural ceramics, Ceramic Nanocomposites (1991), Nippon Seramikkusu Kyokai Gakujutsu Ronbunshi/Journal of the Ceramic Society of Japan, 99 (1154), pp. 974-982.

[2] M. Sternitzke, Review: structural ceramic nanocomposites, J. Eur. Ceram. Soc. 17 (9) (1997) 1061-1082.

[3] H. Schneider, J. Schreuer, B. Hildmann, Structure and properties of mullite: a review, J. Eur. Ceram. Soc. 28 (2) (2008) 329-344.

[4] R. Torrecillas, J. Calderon, J. Moya, M. Reece, C. Davies, C. Olagnon, G. Fantozzi, Suitability of mullite for high temperature applications, J. Eur. Ceram. Soc. 19 (1999) 2519-2527.

[5] Y.-F. Chen, M.-C. Wang, M.-H. Hon, Phase transformation and growth of mullite in kaolin ceramics, J. Eur. Ceram. Soc. 24 (8) (2004) $2389-2397$.

[6] M. Hamidouche, N. Bouaouadja, C. Olagnon, G. Fantozzi, Thermal shock behavior of mullite ceramic, Ceram. Int. 29 (2003) 599-609.

[7] Svante Prochazka, Jay S. Wallace, Nils Claussen, Microstructure of sintered mullite-zirconia composites, J. Am. Ceram. Soc. 66 (8) (1983) c125-c127.

[8] J.S. Moya, M.I. Osendi, Microstructure and mechanical properties of mullite/ZrO 2 composites, J. Mater. Sci. 19 (9) (1984) 2909-2914.

[9] N. Claussen, Strengthening strategies for $\mathrm{ZrO}_{2}$-toughened ceramics at high temperatures, Mater. Sci. Eng. 71 (1985) 23-38 (C).

[10] S. Lathabai, D.G. Hay, F. Wagner, N. Claussen, Reaction-bonded mullite/ zirconia composites, J. Am. Ceram. Soc. 79 (1) (1996) 248-256.

[11] M. Hamidouche, N. Bouaouadja, H. Osmani, R. Torrecillas, G. Fantozzi, Thermomechanical behaviour of mullite-zirconia composite, J. Eur. Ceram. Soc. 16 (4) (1996) 441-445.

[12] S.-K. Zhao, Y. Huang, C.-A. Wang, X.-X. Huang, J.-K. Guo, Mullite formation from reaction sintering of $\mathrm{ZrSiO}_{4} / \alpha-\mathrm{Al}_{2} \mathrm{O}_{3}$ mixtures, Mater. Lett. 57 (11) (2003) 1716-1722.

[13] T. Ebadzadeh, E. Ghasemi, Influence of starting materials on the reaction sintering of mullite- $\mathrm{ZrO}_{2}$ composites, Mater. Sci. Eng. A 283 (1-2) (2000) 289-297.

[14] L.B. Garrido, E.F. Aglietti, Zircon based ceramics by colloidal processing, Ceram. Int. 27 (5) (2001) 491-499.

[15] N.M. Rendtorff, L.B. Garrido, E.F. Aglietti, Thermal shock behavior of dense mullite-zirconia composites obtained by two processing routes, Ceram. Int. 34 (8) (2008) 2017-2024.

[16] B.-Y. Ma, Y. Li, Y.-C. Zhai, Synthesis of zirconia-mullite composite materials with fly ash as raw material by reaction sintering process, J. Northeast. Univ. (Dongbei Daxue Xuebao) 31 (6) (2010) 852-855.

[17] M.N. Ibarra Castro, J.M. Almanza Robles, D.A. Cortés Hernández, J.C. Escobedo Bocardo, J. Torres Torres, Development of mullite/ zirconia composites from a mixture of aluminum dross and zircón, Ceram. Int. 35 (2) (2009) 921-924.

[18] M.K. Haldar, Effect of magnesia additions on the properties of zirconiamullite composites derived from sillimanite beach sand, Ceram. Int. 29 (5) (2003) 573-581.

[19] M.K. Haldar, G. Banerjee, Properties of zirconia-mullite composites prepared from beach sand sillimanite, Mater. Lett. 57 (22-23) (2003) 3513-3520.

[20] D. Chandra, G.C. Das, U. Sengupta, S. Maitra, Studies on the reaction sintered zirconia-mullite-alumina composites with titania as additive, Ceramica 59 (351) (2013) 487-494.

[21] S.-Q. Liang, R. Liu, X.-P. Tan, D.-K. Guan, Effect of TiO 2 addition on zirconia-mullite composites fabricated by in-situ controlled crystallization of Si-Al-Zr-O amorphous bulk, J. Central South Univ. Technol. 18 (5) (2011) 1321-1325.

[22] T. Ebadzadeh, E. Ghasemi, Effect of $\mathrm{TiO} 2$ addition on the stability of t$\mathrm{ZrO}_{2}$ in mullite- $\mathrm{ZrO}{ }_{2}$ composites prepared from various starting materials, Ceram. Int. 28 (4) (2002) 447-450.
[23] S.H. Badiee, S. Otroj, M. Rahmani, The effect of nano- $\mathrm{TiO}_{2}$ addition on the properties of mullite- zirconia composites prepared by slip casting, Sci. Sinter. 44 (3) (2012) 341-354.

[24] P. Ganesh Babu, C. Kumar, K. Ravichandran, P. Manohar, Synthesis and characterization of zirconium tin titanate $\left(\mathrm{Zr}_{0.8} \mathrm{Sn}_{0.2} \mathrm{TiO}_{4}\right)$, Int. J. ChemTech Res. 5 (5) (2013) 2122-2129.

[25] W. Yuan, C. Deng, H. Zhu, J. Li, Preparation of zirconium titanate ceramics by alloy oxidation method, Adv. Mater. Res. 634-638 (1) (2013) 2402-2405.

[26] A. George, S. Solomon, J.K. Thomas, A. John, Characterizations and electrical properties of $\mathrm{ZrTiO}_{4}$ ceramic, Mater. Res. Bull. 47 (11) (2012) 3141-3147.

[27] E. López-López, C. Baudín, R. Moreno, I. Santacruz, L. Leon-Reina, M.A.G. Aranda, Structural characterization of bulk $\mathrm{ZrTiO}_{4}$ and its potential for thermal shock applications, J. Eur. Ceram. Soc. 32 (2) (2012) 299-306.

[28] E. López-López, R. Moreno, C. Baudín, Zirconium titanate: Stability and thermal expansion [Titanato de circonio: estabilidad termodinámica y expansión térmica], Bol. Sociedad Espanola Ceram Vidr. 50 (4) (2011) 169-178.

[29] Y. Park, Y. Kim, Influence on cooling rate on the physical properties of tin modified zirconium titanate, J. Mater. Sci. Lett. 15 (1996) 853-855.

[30] G. Gusmano Bianco, R. Freer, P. Smith, Zirconium titanate microwave dielectrics prepared via polymeric precursor route, J. Eur. Ceram. Soc. 19 (1999) 959-963.

[31] S. Hirano, T. Hayashi, A. Hattori, Chemical processing and mircrowave characteristic of $(\mathrm{Zr}, \mathrm{Sn}) \mathrm{TiO} 4$ microwave dielectrics, J. Am. Ceram. Soc. 74 (1991) 1320-1324.

[32] R. Christoffersen, P.K. Davies, X. Wei, T. Negas, Effect of Sn substitution on cation ordering in $\left(\mathrm{Zr}_{1-\mathrm{x}} \mathrm{Sn}_{\mathrm{x}}\right) \mathrm{TiO}_{4}$ microwave dielectric ceramics, J. Am. Ceram. Soc. 77 (1994) 441-450.

[33] J.A. Navio, F.J. Marchena, M. Macias, P.J. Sanchez-Soto, P. Pichat, Formation of zirconium titanate powder from a sol-gel prepared reactive precursor, J. Mater. Sci. 27 (9) (1992) 2463-2467.

[34] A. Borrell, M.D. Salvador, V.G. Rocha, A. Fernández, A. Gómez, E. López-López, R. Moreno, $\mathrm{ZrTiO}_{4}$ materials obtained by spark plasma reaction-sintering, Compos. Part B: Eng. 56 (2014) 330-335.

[35] M. Dondi, F. Matteucci, G. Cruciani, Zirconium titanate ceramic pigments: crystal structure, optical spectroscopy and technological properties, J. Solid State Chem. 179 (1) (2006) 233-246.

[36] M.F. Melo, J.S. Moya, P. Pena, S. De Aza, Multicomponent toughened ceramic materials obtained by reaction sintering - Part 3 System $\mathrm{ZrO}_{2}$ $\mathrm{Al}_{2} \mathrm{O}_{3}-\mathrm{SiO}_{2}-\mathrm{TiO}_{2}$, J. Mater. Sci. 20 (8) (1985) 2711-2718.

[37] A. Kaiser, M. Lobert, R. Telle, Thermal stability of zircon $\left(\mathrm{ZrSiO}_{4}\right)$, J. Eur. Ceram. Soc. 28 (11) (2008) 2199-2211.

[38] I.D. Alecu, R.J. Stead, Further tailoring of material properties in nonequimolar aluminium titanate ceramic materials, J. Eur. Ceram. Soc. 27 (2-3) (2007) 679-682.

[39] S. Bueno, M.G. Hernández, T. Sánchez, J.J. Anaya, C. Baudín, Nondestructive characterisation of alumina/aluminium titanate composites using a micromechanical model and ultrasonic determinations: Part I Evaluation of the effective elastic constants of aluminium titanate, Ceram. Int. 34 (1) (2008) 181-188.

[40] F.H. Perera, A. Pajares, J.J. Meléndez, Strength of aluminium titanate/ mullite composites containing thermal stabilizers, J. Eur. Ceram. Soc. 31 (9) (2011) 1695-1701.

[41] E. López-López, J.P. Erauw, R. Moreno, C. Baudín, F. Cambier, Elastic behaviour of zirconium titanate bulk material at room and high temperature, J. Eur. Ceram. Soc. 32 (16) (2012) 4083-4089.

[42] E. López-López, C. Baudín, R. Moreno, I. Santacruz, L. Leon-Reina, M. A.G. Aranda, Structural characterization of bulk $\mathrm{ZrTiO}_{4}$ and its potential for thermal shock applications, J. Eur. Ceram. Soc. 32 (2) (2012) 299-306.

[43] R.W. Lynch, B. Morosin, Thermal expansion, compressibility, and polymorphism in hafnium and zirconium titanates, J. Am. Ceram. Soc., vol. 55(8), 1972, pp. 409-413.

[44] G. Suárez, S. Acevedo, N.M. Rendtorff, L.B. Garrido, E.F. Aglietti, Colloidal processing, sintering and mechanical properties of zircon $\left(\mathrm{ZrSiO}_{4}\right)$, Ceram. Int. 41 (1) (2015) 1015-1021. 
[45] S. Bueno, R. Moreno, C. Baudín, Design and processing of $\mathrm{Al}_{2} \mathrm{O}_{3}-$ $\mathrm{Al}_{2} \mathrm{TiO}_{5}$ layered structures, J. Eur. Ceram. Soc. 25 (6) (2005) 847-856.

[46] S. Bueno, R. Moreno, C. Baudín, Reaction sintered $\mathrm{Al}_{2} \mathrm{O}_{3} / \mathrm{Al}_{2} \mathrm{TiO}_{5}$ microcrack-free composites obtained by colloidal filtration, J. Eur. Ceram. Soc. 24 (9) (2004) 2785-2791.

[47] T. Molina, M. Vicent, E. Sánchez, R. Moreno, Dispersion and reaction sintering of alumina-titania mixtures, Mater. Res. Bull. 47 (9) (2012) 2469-2474.

[48] S. Fazio, J. Guzmán, M.T. Colomer, A. Salomoni, R. Moreno, Colloidal stability of nanosized titania aqueous suspensions, J. Eur. Ceram. Soc. 28 (11) (2008) 2171-2176.

[49] T. Molina, M. Vicent, E. Sánchez, R. Moreno, Dispersion and reaction sintering of alumina-titania mixtures, Mater. Res. Bull. 47 (9) (2012) 2469-2474.

[50] R. Chaim, M. Levin, A. Shlayer, C. Estournes, Sintering and densification of nanocrystalline ceramic oxide powders: a review, Adv. Appl. Ceram. 107 (3) (2008) 159-169.

[51] H.M. Rietveld, A profile refinement method for nuclear and magnetic structures, J. Appl. Crystallogr. 2 (1969) 65-71.

[52] R.A. Young, The Rietveld Method, IUCr, Oxford University Press, New York, 1995.

[53] D.L. Bish, J.E. Post, Quantitative mineralogical analysis using the Rietveld full-pattern fitting method, Am. Mineral. 78 (9-10) (1993) 932-940.

[54] H. Miyazaki, H. Hyuga, Y. Yoshizawa, K. Hirao, T. Ohji, Measurement of indentation fracture toughness of silicon nitride ceramics: I, effect of microstructure of materials, Key Eng. Mater. 352 (2007) 41-44.
[55] K. Niihara, R. Morena, D.P.H. Hasselman, Evaluation of $K_{\mathrm{IC}}$ of brittle solids by the indentation method with low crack-to-indent ratios, J. Mater. Sci. Lett. 1 (1982) 13-16.

[56] D.A.H. Hanaor, C.C. Sorrell, Review of the anatase to rutile phase transformation, J. Mater. Sci. 46 (4) (2011) 855-874.

[57] N. Rendtorff, L. Garrido, E. Aglietti, Mullite-zirconia-zircon composites: properties and thermal shock resistance, Ceram. Int. 35 (2) (2009) 779-786.

[58] N.M. Rendtorff, L.B. Garrido, E.F. Aglietti, Zirconia toughening of mullite-zirconia-zircon composites obtained by direct sintering, Ceram. Int. 36 (2) (2010) 781-788.

[59] N.M. Rendtorff, L.B. Garrido, E.F. Aglietti, Mechanical and fracture properties of zircon-mullite composites obtained by direct sintering, Ceram. Int. 35 (7) (2009) 2907-2913.

[60] N.M. Rendtorff, G. Suárez, Y. Sakka, E.F. Aglietti, Dense mullite zirconia composites obtained from the reaction sintering of milled stoichiometric alumina zircon mixtures by SPS, Ceram. Int. 40 (3) (2014) $4461-4470$.

[61] T. Ohji, Y.-K. Jeong, Y.-H. Choa, K. Niihara, Strengthening and toughening mechanisms of ceramic nanocomposites, J. Am. Ceram. Soc. 81 (6) (1998) 1453-1460.

[62] P.M. Kelly, L.R.F. Rose, The martensitic transformation in ceramics-Its role in transformation toughening, Prog. Mater. Sci. 47 (5) (2002) 463-557. 